\title{
DISCURSIVE STRATEGIES OF NEWS PRESENTATION IN THE SELECTED ONLINE NEWSPAPERS
}

\author{
Mia Perlina \\ Universitas Pamulang, Banten \\ dosen00322@unpam.ac.id
}

\begin{abstract}
Research on media language has still attracted a great deal of attention from discourse analysts due to the fact that the news delivered may vary, following the issues growing in society. This study, then, concentrated on the news reports regarding the issue of KPK vs. Polri conflict in three selected online newspapers, namely The Jakarta Post, the Jakarta Globe, and Tempo.Co. By adopting Bell's (2007) work, the study analyzed the news text structure at the discourse level, where it dealt with the process of inclusion and exclusion in the headline, lead, and news scheme (contents). The data revealed that while The Jakarta Post (JP) tended to be objective in delivering the news in relation to Budi Gunawan's case, the discursive strategy was practiced by The Jakarta Globe (JG) and Tempo through the news text structure at the discourse level. JG, in that case, gave the positive appraisal to Budi Gunawan (Polri) more than to KPK. Tempo, on the other hand, preferred to highlight the role of President Joko Widodo on Budi Gunawan's case. In conclusion, the issue of media partiality in the news reports, especially on KPK vs. Polri conflict, can still be found even though it exactly opposes to journalism ethics and standards. Owing to this, it is suggested that media should pay more attention to the neutrality and objectivity in every news report.
\end{abstract}

Keywords: $C D A$, media, partiality, representation

\section{INTRODUCTION}

Recently there has been much attention to news reports. In Indonesia, in particular, consuming the news reports from mass media seems to be a new lifestyle. Therefore, not without reason mass media always update the latest news, lasting even in a second. Besides, the mass media also provide more and more attention to certain topics that audiences want. This fact, then, indicates that a big competition among mass media can occur in presenting information concerned, both visually and textually.

For researchers and linguists, the way the mass media present the information or news, whether through visual (i.e. images), textual (e.g. written), or both, attract their attention not only to focus on the contents of the news but also to describe how the language is utilized, such as the word choices, sentence constructions, and implied meanings of certain texts, which may represent identities or ideology of the mass media on their own works. Fowler (1991, p.66) points out that each event represented in a news text implies representation from an ideological standpoint. Investigating on such issue, then, is called Critical Discourse Analysis.

Critical Discourse Analysis (henceforth CDA), according to Fairclough (1992b), means that the technique used for the study of textual practice and language use as social and 
cultural practice. Van Dijk (1993, p.352), in addition, defines that CDA is "a type of discourse analytical research that primarily studies the way social power abuse, dominance, and inequality are enacted, reproduced, and resisted by text and talk in the social and political context". Van Dijk (1998, pp.26-27), further, notes that there are three main concepts in CDA; they are power, dominance, and access. To put it simply, CDA deals with the means to analyze the utilization of language (both spoken and written), which focuses not only on explicit but also implicit meanings contained in a discourse.

One of the research studies which currently concerns with Critical Discourse Analysis approach is the language use of news reports, both in printed and electronic media. This is because many of the mass media represent their identities, ideologies, or perspectives in the news conveyed. Zifanna \& Fasya's (2013) study, for example, showed that Republika appreciated more than Koran Tempo in the case of representing the president PKS, Luthfi Hasan Ishaq (LHI), as the suspect of bribery due to the fact that the ideology of Republika is more or less the same as PKS (Partai Keadilan Sosial or Party of Justice). Another, Yuliana \& Goeridno (2004) discussed the influence of gender on the news written or reported. In other words, the ways the male or female journalists write the news may represent their identities. In addition, Suroso (2003) examined the perspectives of Indonesian daily newspapers at the beginning of the Reformation era. He notes that the perspectives of each newspaper can be seen from the strategy of presenting the news delivered, such as the use of titles, topics, and themes and their structures, and from the forms of linguistic features, such as lexical choices, the use of metaphors, nominalizations, and speech acts. In the same way, in her thesis, Iswara (2012) analyzed the perspectives of four newspapers (two Indonesian newspapers and two Malay newspapers) towards the issue of Tanjung Balai event. Furthermore, in 2009 Subagyo examined opinions of five national newspapers (Kompas, Koran Tempo, Republika, Suara Pembaruan, and Media Indonesia) towards terrorism. Still focusing on the issue of terrorism, Subagyo (2011) also studied the frames and manifestations of four national newspapers (Kompas, Koran Tempo, Republika, and Suara Pembaruan) and recently investigated motivated names for the event of Bom Bali 1 (2013). Moreover, Renström (2012) addressed the power relations and ideologies represented in the news discourses about Occupy Wall Street protest in New York Times and New York Post. Later, Nawaz, Bilal, Kalsoom, Fayyaz, and Nayyar (2013) investigated the language use of five popular newspapers of Pakistan by comparing the headlines on the same issue to see the ideology of each newspaper. They found that different views of the five newspapers towards the issue were shown through the lexical items chosen, and these views represented the ideologies of the owners. Meanwhile, in his dissertation Pasha (2011) studied the Islamists' ideological representation in the Egyptian newspaper, Al-Ahram. He concluded that the Egyptian regimes have been practicing a constant and systematic strategy of exclusionary nature towards the Muslim Brotherhood. Other research studies are 'racism in the news' (Teo, 2000), 
multimodal analysis (Harimansyah, 2011), discursive representations in China's English press (Alvaro, 2013), and news coverage of Costa Rican diplomatic shift (Callelo \& Chen, 2013).

Though many previous studies have focused on the language utilized in news reports, research on this topic has still received a great deal of attention from discourse analysts due to the fact that the news written or reported may vary, following the issues growing in society. In other words, journalists tend to inform the latest news on the issues that public want. At the same time, the language produced by the journalists may probably be constructed differently from one issue to another. In a way of how the journalists write or report the news, then, may reflect their identities, ideologies, or perspectives on the issues concerned. Besides, most previous studies conducted in Indonesia, particularly, examined daily Indonesian newspapers. The present study, thus, aims to describe the strategy of news presentation employed in three online English newspapers of Indonesia on the issue of KPK vs. Polri conflict.

KPK (Komisi Pemberantasan Korupsi) is the Corruption Eradication Commision of Indonesia which is formed to conduct anti-corruption activities under Law No. 30 of 2002, whereas Polri (Kepolisian Republik Indonesia) is the official force of Indonesia, which had formerly been part of Tentara Nasional Indonesia (Indonesian National Armed Forces). The conflict between KPK and Polri began by the action of KPK having tapped Susno Duadji's phone, Indonesian Police chief detective, while investigating a corruption case in April 2009. Being angry with the KPK's action against him, Susno Duadji compared the KPK to a gecko fighting a crocodile meaning the police, or it was then well known as cicak vs. buaya. In June 2010, then, the conflict between KPK and Polri occurred for the second time. In this case, two senior police officers, they are Insp. Gen. Djoko Susilo (a two-star general), and Brig. Gen. Didik Purnomo (a one-star general) were involved in the procurement of driving simulators at the National Police (Polri). However, this conflict was intervened by the then Indonesian president, Susilo Bambang Yudhoyono.

Two years later, the KPK began investigating another senior police officer, Budi Gunawan, who was subsequently nominated for the post of police chief. The KPK then named Budi a suspect and his nomination was withdrawn. The police subsequently took revenge by charging three KPK commissioners with criminal offenses, they are Abraham Samad (chairman of the KPK), Bambang Wijayanto (deputy chairman of KPK) and Adnan Pandu Praja (deputy chairman of the KPK). Towards the conflict between KPK and Polri, then, the way the news was written may represent the media ideologies or perspectives. The present study, thus, is highly interested in investigating this new conflict between KPK and Polri in terms of the language utilizations employed by three selected online English newspapers of Indonesia.

The issue of KPK vs. Polri conflict was chosen due to the fact that this issue has attracted much attention from the public at that time, and of course, the conflict itself involved two big law institutions in Indonesia. In addition, the issue of KPK vs. Polri conflict, which was known as the term 
'gecko vs. crocodile', has occurred three times. Therefore, it is considered interesting to analyze how the news presentation was delivered, which may potentially reflect perspectives on the issue concerned. This study, however, only focused on the case of Budi Gunawan as a graft suspect, in which this case was considered as the beginning of KPK vs. Polri conflict Volume 3 occurred.

\section{LITERATURE REVIEW}

It is worth noting that news presented by journalists is constructed and influenced by "the criteria of newsworthiness framed by state and economic domains" (Allan, 2004, p.3, as quoted in Renstrom, 2012, p.1). In other words, the news conveyed is not a natural occurrence and may contain ideology of the news writers, editors, and/or owner of the institutions for whom the journalists work. As a result, the journalists have to consider which events are included and excluded in the news and how the contents of the news are delivered. This issue, then, leads us to the notion of objectivity.

Objectivity refers to "the state or quality of being objective and fair" (Cambridge.org, 2017). In the same way, Oxforddictionaries.com (2017) defines objectivity as "the quality of being objective". The concept of objectivity is then expected to be maintained in news reporting. That is, journalists keep providing facts and being neutral and unbiased to the news reports delivered. As Zhang (2012, p.1, as cited in Iswara, 2012, p.2) claimed that "the news the reporters convey to public bear neutrality, objectivity, and being unbiased". Further, McQuail (1992) noted that objectivity of news media will reflect factuality by providing the truth and relevance of the news related rather than partiality, in which it is shown by being biased and non-balanced to the news contents delivered. In facts, objectivity in the most news reports today is far from the expectation since, according to Ward (2004, p.13), “journalists are under intense commercial pressure to sell the news, please their bosses, and write their stories according to the political slant of their news organization". Hence, the ways the journalists write the news is likely to be influenced by the ideology of the partisanship for which they work. Similarly, there would be a great power that controls the journalists in reporting the news. The news presented, then, tends to be subjective and may be constructed discursively. Once the news composed is manipulated, power and ideology are detected.

Detecting power abuse and ideology in news reporting can be reflected by the choice of lexical items. Lexical choices, according to Fowler (1991), are very crucial in the construction of meaning. Symson and Myar (2010), further, noted that lexical choices can shape readers' opinions towards the news delivered. In addition, Huckin (1995, p.101) argued that "labels may carry unavoidable connotations". For example, the choice of noun-pairing freedom fighters vs. terrorists (Kress, 1983; Van Dijk, 1995; \& Clark, 1998) reflects the ideology of those who name; the opponents prefer to use terrorists, and the proponents, otherwise, tend to use freedom fighters.

Furthermore, representing perspectives or ideology in news reporting can also be seen through the use of sentence structure. For instance, 
active sentences, as opposed to passive, normally clarify who did what to whom? In other words, in active sentences each role in a certain event, e.g. agent, is usually clearly mentioned. Let us examine the following sentences:

(a) wakil ketua KPK Zulkarnaen dilaporkan ke Bareskrim Polri (TVOne)

(b) Jatim AM laporkan dugaan korupsi wakil ketua KPK Zulkarnaen (MetroTV)

(Zifana, 2015, p.35)

From the sentence (a) passive voice was preferred to use rather than active voice. This may indicate that TVOne emphasized more on the role of wakil ketua KPK (KPK vice chairman) Zulkarnaen, and clearly showed us that TVOne preferred not to mention the agent, who did the report. Otherwise, from the sentence (b) active voice was preferred to use by MetroTV. Therefore, the sentence (b) definitely clearly showed us 'who did what to whom?', in which it was Jatim AM who reported KPK vice chairman Zulkarnaen in the alleged corruption case.

Moreover, perspectives may also be seen through how the news texts are structured. This refers to what Pan and Kosicki (2012) called as "script structure". This feature, in general, discusses the familiar five Ws and one $\mathrm{H}$ in the news texts: who, what, when, where, why, and how. Pan and Kosicki (1993, p.60) stated that "Even though the five Ws and one $\mathrm{H}$ do not have to be present in every single story, these are categories of information that a reporter is expected to gather and report". On the basis of those questions, the structure of news texts to deliver the related information may be discursively constructed and influenced by the ideology or viewpoints of the writers or journalists in news writing. As Bennet (1988, cited in Pan and Kosicki, 1993, p.60) argued that "news often appears to be excessively fragmented, personalized, and dramatized to some of its critics". This study then was conducted to find out whether The Jakarta Post, the Jakarta Globe, and Tempo.Co adopt objectivity to the issue of KPK vs. Polri conflict Volume 3 through analyzing the language use, especially at the discourse level.

Meanwhile, Gerbner (1985, as cited in Suroso, 2003) asserts that one of the linguistic features to see perspectives in the news stories is that of the way how the news is reported to readers. In other words, the structure of news presentation may be discursively construed. Bell (2007, pp. 67-70) then describes guidance on how to analyze and interpret structures of a news story, in which eighteen steps are suggested. The guidance is discussed as follows.

\section{What}

1. Headline: What events take place in the headline? Summarize and number.

2. Lead: What events take place in the lead or intro? Summarize and number.

3. Events:

What events take place in the story? Summarize and number, then enter numbers alongside each sentence of the story.

Re-categorize events in headline and lead as necessary to correspond with the fuller picture you now have from the story as a whole.

What is the central event of the whole story? (Usually the main 'hard' news event in the lead)

\section{Headline, lead and story}


What is the relationship of the headline to the lead?

What is the relationship of the lead to the story as a whole?

\section{Who}

5. Story attribution: Is the story as a whole attributed? To whom (agency, journalist)?

6. Sources attribution

Beside each sentence, note down whom it is attributed to (if anyone).

Precisely what is attributed and to whom?

What speech verb is used in the attributions? (list)

\section{News actors}

What news actors are mentioned? (list: people, organizations, nations, etc.)

How are they labeled or referred to? (list)

Does specifying who the news actors are modify the event structure you developed earlier?

\section{Where}

\section{Places}

What place expressions are used? (list)

Where do they occur in the story? (sentence number)

\section{Place structure}

What locations does the story take place in? (list)

Does specifying locations in this way modify the event structure you developed earlier?

\section{When}

\section{Times}

What time expressions are used in the story? (list)

Where do they occur in the story? (sentence number)

\section{Time structure}

What is the time structure of the story? Take the time of the central event as Time 0 . Label earlier events as Time $-1,-2$, etc, and later events as Time $+1,+2$ etc. in the chronological sequence in which they actually occurred. Beside each sentence, note down the number of the time or times at which the actions mentioned there occurred.

\section{Background}

Is any background given (events prior to the central action - either recent previous events or more historical events)?

\section{Commentary}

Is there any commentary on events? evaluation of events (editorializing)? Context, for what has happened? Expectations of how the situation will develop?

\section{Follow-up}

Is there any follow-up to the central action of each event (subsequent events, either reaction (verbal) or consequences (non-verbal))?

\section{Event and Discourse Structure}

\section{Event structure}

Collate your successive recategorizations of what happened in the story, drawing on news actors, place and time as well as the actions themselves.

List in chronological order the events and their associated actors, times and places and the sentence numbers in which they occur (as in table 1 example). This represents the event structure as you finally assess it to be.

Note any alternatives, which represent discrepancies or unclarities in the story itself.

\section{Discourse structure}


At this stage, you can draw a tree diagram of the discourse structure. Note that the apparent order which these example figures display is only arrived at after a succession of rough drafts! Such a structure is also idealized in the sense that it masks ambiguities and unclarities.

\section{Cohesion}

What linkages are expressed or implied between the sentences or events in the story? How? (list)

What linkages are omitted? (list)

\section{Confusion}

Has it now been possible to say precisely what happened in the story?

Or are there still ambiguities, gaps or confusions, as exemplified in the possibility of an alternative event or discourse structures? (list, explain)

\section{METHOD}

The present study is qualitative research, which aims to find out the strategy of news presentation in the three online English newspapers of Indonesia to represent their perspectives on the issue of KPK vs. Polri conflict in the case of Budi Gunawan's (BG) status as a graft suspect, where this issue occurred in January 2015. Describing the discourse structure of the news articles, the current study was gradually hoped to be able to reveal the discursive strategies to represent ideology or perspectives in the news presentation of the selected news articles.

The data were sourced from three online English newspapers of Indonesia, namely: (1) The Jakarta Post; (2) The Jakarta Globe; and (3) Tempo.Co which were subsequently named as JP, JG, and Tempo. Online newspapers, rather than printed newspapers, were chosen due to the fact that most people today consume any information (including news) from the internet.

There are many articles that are related to the issue of the conflict between KPK and Polri occurred in 2015 (e.g. Budi Gunawan's status as a graft suspect, Hasto Kristiyanto's accusation towards Abraham Samad, the arrest of Bambang Wijayanto, Budi Gunawan's pretrial, etc). It was decided, then, that this study focused only on the case of Budi Gunawan's status as a graft suspect, which was issued as the beginning at which KPK and Polri conflict Volume 3 happened. This decision was intended to be more focused and get a profound understanding about the strategy of news presentation employed in each of the selected articles. The following were the titles of the three news articles:

Table 1. Titles of the news articles

\begin{tabular}{|c|c|c|c|c|}
\hline $\begin{array}{l}\text { Arti } \\
\text { cle }\end{array}$ & Media & Title & $\begin{array}{c}\text { Author } \\
\text { s }\end{array}$ & Dates \\
\hline JP & $\begin{array}{l}\text { The } \\
\text { Jakarta } \\
\text { Post }\end{array}$ & $\begin{array}{l}\text { KPK nixes } \\
\text { Jokowi's } \\
\text { choice for top } \\
\text { cop post }\end{array}$ & $\begin{array}{l}\text { Haeril } \\
\text { Halim } \\
\text { and } \\
\text { Fedina } \\
\text { S. } \\
\text { Sundar } \\
\text { yani }\end{array}$ & $\begin{array}{l}\text { Wednesd } \\
\text { ay, } \\
\text { January } \\
\text { 14 2015, } \\
\text { 9:17 AM }\end{array}$ \\
\hline JG & $\begin{array}{l}\text { The } \\
\text { Jakarta } \\
\text { Globe }\end{array}$ & $\begin{array}{l}\text { Police Chief } \\
\text { Candidate } \\
\text { Budi Named } \\
\text { Corruption } \\
\text { Suspect by } \\
\text { KPK }\end{array}$ & $\begin{array}{l}\text { Jakarta } \\
\text { Globe }\end{array}$ & $\begin{array}{l}\text { Tuesday, } \\
\text { January } \\
132015 \text {, } \\
03: 03 \\
\text { PM }\end{array}$ \\
\hline $\begin{array}{c}\text { Tem } \\
\text { po }\end{array}$ & $\begin{array}{l}\text { Tempo } \\
\text {.Co }\end{array}$ & $\begin{array}{l}\text { KPK: Jokowi } \\
\text { Has Been } \\
\text { Told about } \\
\text { Budi } \\
\text { Gunawan's } \\
\text { Red Marks }\end{array}$ & $\begin{array}{l}\text { Linda } \\
\text { Trianita }\end{array}$ & $\begin{array}{l}\text { Tuesday, } \\
\text { January } \\
132015, \\
07: 18 \\
\text { PM }\end{array}$ \\
\hline
\end{tabular}

Noting that all the data were downloaded from the official media website of The Jakarta Post, The Jakarta Globe, and Tempo.Co.

Furthermore, the analysis focused only on the three elements suggested by Bell (2007), those are as follows. 
(1) Headline (abbreviated as HL)

(2) Lead

As pointed out by many news discourse analysts, the number of readers who skim headlines or reading the first or three sentences in the lead outnumbers those who read full stories. Therefore, headlines and leads serve important strategic cues to control the way readers process and make sense of the report (Teo, 2000, p.14). In the way how the headlines and lead are utilized, then, may construct ideologies or perspectives.

(3) Story scheme (the body of the news story)

To be more comprehensive and critical, this study not only discusses the point of view of average readers (those who read the headlines and (part of) the leads, but it also approaches the perspective of those who read all or most of the newspaper sections. This way, thus, makes the data more valid.

It should be worth noting that when analyzing the headlines, leads, and story scheme the study highlights the event(s) included and/or excluded in the headline, lead, and story (body of the news story).

\section{DISCUSSION}

This section is dedicated to deliver the results of the study, in which this study addresses the structure of news discourse, focusing on what events (topics) are included and excluded in the headline, lead and story scheme (the body of the news story within each article selected. Those three elements, thus, will be discussed in turn.

First of all, the result shows that the headline used in the articles selected is different from one to another. For example, in line with the participants, JP involves KPK and Jokowi as their participants, while JG involves BG and KPK, and Tempo prefers to involve KPK, Jokowi, and BG. Out of three newspapers, hence, we can assume that Tempo tries to balance the roles of those three participants in relation to BG's status as a graft suspect. Furthermore, the headlines employed also specify that each newspaper tells different events despite having the same main topic or key event (BG's status as a graft suspect). Thus, this makes clear what event is included and excluded in the headline. For instance, JP, chronologically, seems to narrate two events in the headline: (1) Jokowi's choice for top cop post (or BG's nomination) and (2) KPK nixes Jokowi's choice. Meanwhile, Tempo prefers to highlight BG's red marks rather than BG's nomination or BG's status as a graft suspect. JG, on the other hand, clearly uses BG's status, as the sole event and/or the main topic, in the headline (see Table 2).

Table 2. The news discourse structure: Headline

\begin{tabular}{c|c}
\hline \multirow{2}{*}{ Sources } & \multicolumn{1}{c}{ Headline } \\
\hline \multirow{2}{*}{ JP } & $\begin{array}{c}\text { KPK nixes Jokowi's choice for top cop } \\
\text { post } \\
1 . \quad \text { Jokowi's choice for top cop post }\end{array}$ \\
\hline JG & $\begin{array}{l}\text { Police chief candidate Budi named } \\
\text { corruption suspect by KPK } \\
1 . \quad \text { naming BG as a graft suspect }\end{array}$ \\
\hline Tempo & $\begin{array}{l}\text { KPK: Jokowi has been told about Budi } \\
\text { Gunawan's red marks }\end{array}$ \\
\hline
\end{tabular}

Secondly, it is found that the lead or intro in each article seems to narrate in a different manner. For example, JP specifies four events, while JG and Tempo seem to tell of two events (See Table 3). Even so, each article is referred to BG's status as a graft as the key event. Further, it can be 
seen that the events in the lead of JG and Tempo are closely linked to the events in the headline. For instance, JG directly states the main issue as it does in the headline, while the two events mentioned in Tempo entails the event in the headline. In brief, the lead in JG and Tempo disambiguates the headline. The lead in JP, on the other hand, specifies uniqueness of the headline used, in which the lead clarifies whom Jokowi chose for top cop post, where it is shown by the use of 'National Police chief hopeful Comr. Gen. Budi Gunawan'. However, what KPK nixes Jokowi's choice refers to is not directly stated in the lead and may lead to the confusion, though, admittedly, there must be closely related to the events mentioned within the lead. As Bell (1991, cited in Bell, 1996, p.72) noted that "the majority of headlines are derived solely from lead sentences and not from information further down a story". Thus, it concludes that JG and Tempo utilize frequent pattern to report the news, but $\mathbf{J P}$ is presumed otherwise.

Table 3. The news discourse structure: Lead

\begin{tabular}{|c|c|}
\hline Sources & Lead \\
\hline JP & $\begin{array}{l}\text { 1. KPK declared BG as a graft suspect } \\
\text { 2. BG was nominated as the next police } \\
\text { chief } \\
\text { 3. BG's candidacy was challenged by } \\
\text { antigraft activists } \\
\text { 4. The House is going to hold a } \\
\text { confirmation hearing for Budi's } \\
\text { nomination }\end{array}$ \\
\hline JG & $\begin{array}{l}\text { 1. KPK named BG as a graft suspect } \\
\text { 2. Jokowi nominated BG as the next } \\
\text { police chief }\end{array}$ \\
\hline Tempo & $\begin{array}{l}\text { 1. KPK red flagged BG } \\
\text { 2. Jokowi asked the anti-graft body to } \\
\text { investigate the track records of } \\
\text { ministerial candidates }\end{array}$ \\
\hline
\end{tabular}

Third, as stated earlier that the main topic of the lead in the three article selected is related to BG's status as a graft suspect. Thus, in terms of the number of sentences (later abbreviated S), it can be seen that, out of four events in the story, the issue of BG's status as a graft suspect in JP gets the largest portion, in which it consists of 14 (fourteen) sentences: S1-S6 and S14S21. On the contrary, BG's nomination gets the least sentences, consisting of 3 (three) sentences: S7-S9. The other issues, BG's red marks and BG's confirmation hearing plan, in turn, consist of 4 (four) and 8 (eight) sentences (see Table 4). What is interesting, then, is that it takes until S10 and S11 to make the headline clear what KPK nixes Jokowi's choice refers to and why. S10 and S11 clarify that KPK nixes Jokowi's choice is assumed as an effect of Jokowi's misstep in nominating BG as the next police chief without consulting KPK, along with PPATK, as he did for the ministerial post. Since then, KPK declared BG as a graft suspect, showing why it appears to use KPK nixes Jokowi's choice in the headline. Next, regarding the story scheme in JP, the findings revealed that the story was written based on the events within the lead. This is not without reason that such style is intended to flow the story smoothly and get readers' understanding of the story.

Similar to JP, JG places BG's status as a graft suspect as the main topic or key event, in which this issue is discussed in S1 to S8. Interestingly, within the lead of JG the issue of BG's fit and proper test is not mentioned, but this issue is addressed in the story (S10 - S15). Thus, we can see that there are three events discussed the same in JG and JP, those are: (1) BG's status as a graft suspect; (2) BG's nomination, as in S9; and (3) BG's fit and proper test, as in S10, S14, and S15 (see Table 4). 
Another interesting issue is the exclusion of BG's red marks in JG. In brief, it can be presumed that JG respects more to $\mathrm{BG}$.

Furthermore, Tempo narrates two events in the story, namely: BG's red marks and BG's status as a graft suspect. Unlike JP and JG, Tempo prefers to address more on BG's red marks rather than BG's status, in which the issue is discussed in S1 to S5. What is interesting is any time Tempo presents BG's red marks, Jokowi is always involved. Thus, it assumes that Tempo highlights the role of Jokowi towards BG's case.

Table 4. The news discourse structure:

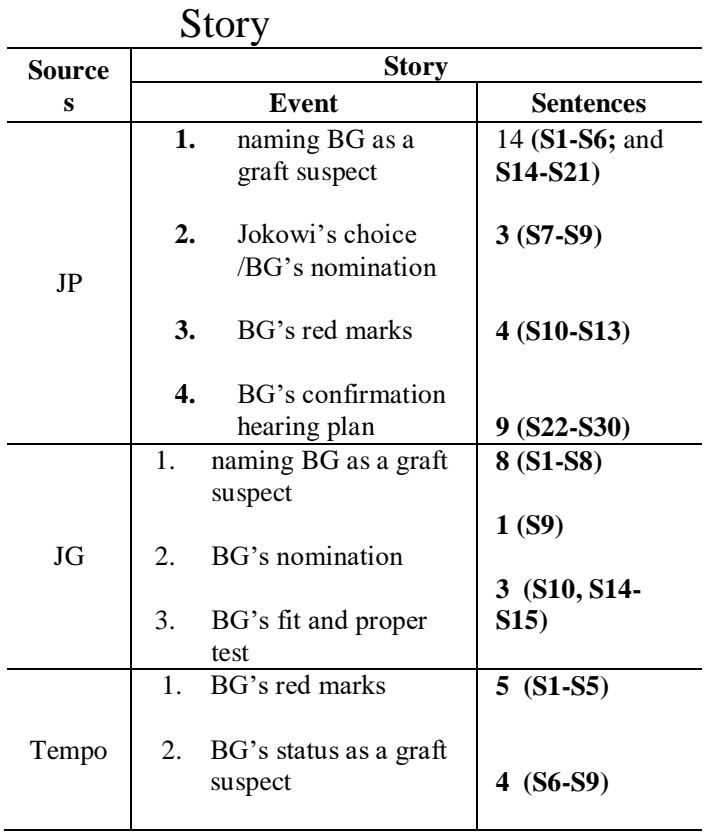

From the explanation above, it can be summarized that there must be news values lying behind the inclusion and exclusion of a certain event or topic in each newspaper, in relation to BG's case. For one thing, for instance, JG, as opposed to JP and Tempo, prefers to exclude BG's red marks, which is assumed that JG gives a positive appraisal more to the role of $\mathrm{BG}$.
Secondly, JG only discusses the role of Jokowi in terms of BG's nomination, but JP and Tempo try to show how the influence of the role of Jokowi towards BG's case, as can be seen from the preference of headline, lead, and story.

\section{CONCLUSION}

The current study has investigated how the news was presented to represent the viewpoint on the issue of KPK vs. Polri conflicts concerning Comr. Gen. Budi Gunawan's case on the basis of Allan Bell's (2007) theory. Three online newspapers have been chosen as the data, they are the Jakarta Post (JP), Jakarta Globe (JG), and Tempo.Co (Tempo). More specifically, this study examined the structure of news texts, where it dealt with the process of inclusion and exclusion in the headline, lead, and story scheme (contents). The data revealed that while JP preferred to be objective in delivering the news concerning Budi Gunawan's case, the discursive strategy was practiced by JG. This was indicated by excluding negative values about Budi Gunawan. Tempo, on the other hand, emphasized more on the role of President Joko Widodo towards Budi Gunawan's case, where it was shown by presenting some KPK's statements which led to the negative perceptions about President Jokowi.

Hence, there was a constant and systematic strategy practiced by JG and Tempo to represent their perspectives on the issue of KPK vs. Polri conflict, especially on Budi Gunawan's case. Through the discourse structure, Both JG and Tempo has shown their positions where exactly they were. Their strategy in presenting the news, then, potentially influences reader's 
perception of the issue concerned. In contrast, by being neutral and objective in delivering the news, JP journalists have indicated where their position was supposed to be in relation to Budi Gunawan's case.

Bearing in mind that the analysis and conclusion of this study are limited by two aspects. First, this study merely examines media representation on the issue of KPK and Polri conflict dealing with Budi Gunawan's case. Thus, it cannot be claimed that the conclusion applies to all other cases involving either KPK or Polri. Secondly, the present study only concentrates on the language used in the three online newspaper selected, so the conclusion cannot be generalized to other media (local or international newspapers), but it rather suggests further research in these areas.

In closing, it is expected that this critical analysis of news report on the issue of KPK vs. Polri conflict contribute to the field of CDA and stimulate further research to be undertaken in areas beyond the newspapers or even the media. In addition, the analysis of this news report shows us that critical analysis is of great significance in assisting news readers not only to achieve a better understanding of what they are reading or of what exactly lies behind every news reporting but to increase critical sensitivity and awareness to the news discourse.

\section{REFERENCES}

Alvaro, J.J. (2013). Discursive representations of a dissident: The case of Liu Xiaobo in China's English press. Discourse and Society, 24(3), 289-314.
Ayuwandari, I \& Syafi'i, M.T. (2013). Bias gender dalam berita kriminal di harian Warta Kota. Konferensi Linguistik Tahunan (KOLITA) Atma Jaya, 11, 103106.

Bell, A. (2007). The discourse structure of news stories. In Teun Van Dijk (Ed.), Discourse studies, (pp. 58-89). London: Sage Publications.

Clark, K. (1998). The linguistics of blame: Representations of women in the Sun's reporting of crimes of sexual violence. In D. Cameron (ed.) The Feminist Critique of Language, pp. 8397. London: Routledge.

Calello, M.C. \& Chen, H. (2013). Taiwan, China, and Central American allies: A discourse analysis of the Costa Rican diplomatic shift news coverage. Taiwan International studies quarterly, 9(1), 139-78.

Fairclough, N. (1992b). Discourse and social change. Cambridge: Polity Press.

Fowler, R. (1991). Language in the news: Discourse and ideology in the press. New York: Routledge.

Huckin, T. (1995). Critical discourse analysis. The Journal of TESOL, 2(3), 95-112.

Iswara, H.W. (2012). A critical look into Indonesia-Malaysia news coverage on Tanjung Balai issue (unpublished master's thesis). The Atma Jaya Catholic University of Indonesia, Jakarta, Indonesia.

Kress, G. (1983). Linguistic and ideological transformations in news reporting. In $\mathrm{H}$. Davis and D. Walton (eds) Language, 
Image, Media, pp. 120-38. Oxford: Blackwell.

McQuail, D. (2002). McQuail's reader in mass communication theory. London: Sage.

Nawaz, S, et al. (2013). Media discourse and their implicit ideologies. Asian journal of social science and humanities, 2(2), 328-237.

Objectivity. (2017). Cambridge.org. Retrieved from http://dictionary.cambridge.org/dict ionary/english/objectivity

Objectivity.

Oxforddictionaries.com. Retrieved from

https://en.oxforddictionaries.com/d efinition/objectivity

Pan, Z. \& Kosicki, G.M. (1993). Framing analysis: An approach to news discourse, Political Communication, 10 (1), 55-75.

Pasha, T. (2011). Islamist in the headlines: Critical discourse analysis of the representation of Muslim Brotherhood in Egyptian newspaper (doctoral dissertation). Retrieved from https://collections.lib.utah.edu/dl _files/98/96/9896e9796741fdf0b d9dbf774846e3849d710b9d.pdf.

Teo, P. (2000). Racism in the news: A critical discourse analysis of news reporting in two Australian newspapers. Discourse and Society, 11(1), 7-49.

Renstrom, C. (2012). Discourses in the news: The case of Occupy Wall Street in the New York Times and New York Post. Sweden: Stockholm University.

Suroso. (2003). Perspektif berita utama politik surat kabar Indonesia pada awal era reformasi: Studi wacana analisis kritis.
Konferensi Linguistik Tahunan (KOLITA) Atma Jaya, 1, 1-4.

Van Dijk, T. (1993). Principles of critical discourse analysis. Discourse and Society, 4(2), 249-83.

Van Dijk, T. (1998). Ideology: A Multidisciplinary approach. London: Sage.

Yuliana, \& Goeridno, R.S.W. (2004). Gender influence in reporting news. Konferensi Linguistik Tahunan (KOLITA) Atma Jaya, 2, 251-55.

Zifana, M. (2015). Cicak versus buaya jilid II dalam perspektif media partisan: Representasi Polri dan KPK dalam pemberitaan wacana kriminalisasi kedua pihak di situs TvOne and MetroTV. Konferensi Linguistik Tahunan (KOLITA) Atma Jaya, 13, 33-37.

Zifana, M \& Fasya, M. (2013). Representasi presiden Partai Keadialan Sejahtera dalam pemberitaan kasus suap daging sapi impor di harian umum Tempo dan Republika. Konferensi Linguistik Tahunan (KOLITA) Atma Jaya, 11, 19399. 